\title{
Effect of Growth Medium Nitrogen and Phosphorus on Nutritional Composition of Lemna Minor (an Alternative Fish and Poultry Feed)
}

Hafiz Ullah ( $\square$ hafizullah@uoch.edu.pk )

Department of Botany University of Chitral, KP, Pakistan

Bakhtiar Gul

Department of Weed Science and Botany, the University of Agriculture Peshawar.

Haroon Khan

Department of Weed Science and Botany, the University of Agriculture Peshawar.

Naveed Akhtar

Islamia College University

Khushnood Ur Rehman

Islamia College University

Umar Zeb

Department of Biology, the university of Haripur

\section{Research Article}

Keywords: Duckweed, Lemna, Aquatic, Nutrients, Proximate composition

Posted Date: November 18th, 2021

DOI: https://doi.org/10.21203/rs.3.rs-1054556/v1

License: (9) (i) This work is licensed under a Creative Commons Attribution 4.0 International License.

Read Full License

Version of Record: A version of this preprint was published at BMC Plant Biology on April 26th, 2022. See the published version at https://doi.org/10.1186/s12870-022-03600-1. 


\section{Abstract}

Duckweed (L. minor) belongs to the family of aquatic macrophytes and grows profoundly on the surface of water reservoirs in polluted areas of Pakistan. The plant can be used as a potential alternative for the fish and poultry industry to comply with the promptly growing demand for feed. Our study investigates the effect of varying concentrations (ppm) of nutrients, like nitrogen $(N)$, phosphorus $(P)$ and their combination (NP) on the carbohydrate, lipid, protein, and mineral ( $\mathrm{Ca}, \mathrm{Mg}, \mathrm{Fe}, \mathrm{Mn} \& \mathrm{Zn}$ ) contents of the duckweed (L. minor). A substantial effect of varying concentrations of N, P and their combinations was seen on all the above-mentioned parameters. Higher protein, lipid, and carbohydrate contents were recorded for 30ppm NP, 20ppm NP, and 10ppm NP, respectively. Minerals contents (Ca, Mg, Fe, Mn \& Zn) increased by $20 \mathrm{ppm}$ in the case of phosphorus and all nitrogen concentrations. The combined application of NP was more effective in boosting up the protein, carbohydrate, and lipid content whereas less effective in increasing the mineral contents. The NP combinations affected all other parameters except the mineral contents. A decline in the concentration of $(N)$ and $(P)$ showed a negative correlation with the nutritional composition of the plant.

\section{Introduction}

Today, agriculturists are facing the challenge of an increasing feed supply for livestock, poultry, and pisciculture. To keep pace with the escalating demand of the major feedstuffs, growers are struggling for an increased supply of animal feed. The shortage of animal feed supply has emerged as the principal problem with the expansion of the poultry and livestock industry. Finding sustainable and economical raw materials to be processed to final feed products is a major source of concern for the feed industry (Fagbenro et al., 2003; Adikwu, 2003; Adejinmi, 2000). The rising cost of conventional animal feed has driven agriculturists to switch to every second option of non-traditional feedstuffs. The alternative of the cheaper non-conventional feed can affect the cost of the ultimate product. Animal nutritionists, therefore, have engaged themselves in finding alternative nonconventional nutritional resources for their animals (Ngou and Mafeni, 1983).

Man has benefited from the aquatic ecosystem since time immemorial. Hydrophytes constitute the biotic component of the aquatic ecosystem which is the baseline of aquatic biodiversity. This implies that water plants are nutritionally rich and play a pivotal role to sustain the life of aquatic animals. Most of the water bodies are inhabited by aquatic weeds that grow vigorously under favorable climatic conditions (Whetstone, 2005). If not managed properly most of the aquatic plants may have a considerable detrimental effect on the habitat directly or indirectly (Lancar and Krake, 2002).

Aquatic weeds are defined as the undesirable vegetation growing in water which if kept unchecked may substantially harm other aquatic biology. With progress in aquatic research, it has become evident that most of the aquatic plants have organic composition making them eligible to be used as animal feed. Aquatic macrophytes thus can play the role of non-conventional feed and can be utilized on a sustainable basis. Among aquatic weeds, the duckweed (Lemna minor) is a potential candidate to be 
used as an economical source of animal feed in a developing country like Pakistan. The plant belongs to the family of tiniest flowering plants the Lemnaceae. It is one of the smallest flowering plants, rich in protein and mineral contents, and can absorb nitrogen, phosphorus, and metals efficiently from water (Logsdon, 1989. It is a free-floating macrophyte about 3.5-10 $\mathrm{mm}$ in size, which thrives in the aquatic habitats of the globe. The genus Lemna is distributed among 12 species worldwide with 5 species occurring in Pakistan (McClure \& Alston 1966).

Globally, soyabean meal is used as the frequent source of feed because of the higher protein percentage (Vang et al., 2001). Lemna minor is as rich in protein content as soyabean meal (Porath et al., 1979). It is one of the cheap sources of minerals and pigments like beta carotene and xanthophylls (Journey et al., 1993) and contains tenfold higher of them as compared to land plants (Mbagwu and Adeniji, 1988). Many other research works show the use of duckweed as potential feed for poultry (Samnang, 1999; Islam et al., 1997; Leng, 1995; Haustein et al., 1990). Duckweed fed to 3-weeks older chicks up to $5 \%$ of mixed feed caused higher weight gain (Truax et al., 1972).

Duckweeds can proliferate rapidly on the surface of stagnant water giving a smooth green look to the water body and acclimatize a broad spectrum of environmental conditions. The plant, having a short life cycle can produce several generations in a short period if favorable environmental conditions are achieved (Journey et al., 1993). The plant can thrive and replicate most excellent in water with $06-33^{\circ} \mathrm{C}$ and can tolerate low temperatures and frost. The dry biomass yield of duckweed ranges between 10-30 tons per hectare annually with a good profile of dietary protein and essential amino acids (Leng et al., 1995).

Imbalance in mineral nutrition highly retards the growth rate and multiplication of the plant. Variation in growth media results in the changeability of the proximate composition of the biomass. In comparison to other growth media, duckweeds grown in hog wastewater manifested a relatively higher content of starch (Cheng and Stomp 2009). The contents of protein in the plant are related to the minerals in the growth medium of the plant.

As the growth of the plant is highly dependent upon the availability and balance of nutrients. The present investigation is aimed to determine whether a change in concentration of Nitrogen and Phosphorus, like other environmental factors, influences the biochemical composition of the plant.

\section{Materials And Methods}

\subsection{Plant Sample Collection}

Fronds of Lemna minor were obtained from standing water bodies and industrial wastewater reservoirs of District Peshawar, Khyber Pakhtunkhwa, Pakistan. The water bodies were open to researchers to collect samples without any restriction.

\subsection{Identification of the Plant Specimen}


Plant specimens were identified by Dr. Bakhtiar Gul, Department of weed and Plant Protection Science, the University of Agriculture, Peshawar Pakistan. The plant specimen was identified keeping in view Flora of Pakistan and other available literature. The collected specimen was deposited in Herbarium, Department of Weed and Plant Protection Science under specimen voucher number WSCl-375.

\subsection{Biomass cultivation}

A trial was conducted in the Department of Weed Science, the University of Agriculture Peshawar, Pakistan. L. minor was collected from the standing water bodies located near the experimental site. The Completely Randomized Design (CRD) with 3 replications, was used as the experimental design. The plants were grown in pots (diameter 21 inches) and depth of 10 inches. A10g fresh biomass of the plant was introduced to each pot already amended and labeled with nitrogen, phosphorus, and their combination (N, P \& NP with a concentration of 10, $20 \& 30$ ppm each). The plants thus full-grown in different concentrations of N, P, and NP were dried in an oven (CARBOLITE GERO-301). Analyses were made for the following proximate compositions.

\subsection{Protein contents}

Percent nitrogen and the crude protein content were investigated by Kjeldahl's method.

Calculations were made based on the following formula.

$$
\begin{aligned}
& \% \mathrm{~N}=\frac{(\mathrm{S}-\mathrm{B}) \times 0.014 \times \mathrm{D} \times 100}{\text { Wt.of sample } \times \mathrm{V}} \\
& 2.5 \text { Lipid contents }
\end{aligned}
$$

The contents of lipid were analyzed through the Soxtec ${ }^{\mathrm{Tm}} 8000$. A $0.5 \mathrm{~g}$ sample was weighed to undergo wet digestion using petroleum ether. To heat the samples electrical heating plates were used. The samples were boiled and rinsed to recover the fat. The flasks containing the fat were weighed to measure the total lipid of the sample. The following formula was used to calculate the percentage of extractable fat.

Fat $($ Extractable $)(\%)=\frac{w_{3}-w_{2}}{w_{1}} \times 100$

\subsection{Carbohydrate contents}

The carbohydrate contents of the samples were calculated using the following formula.

Carbohydrate $(\%)=$ Dry Biomass $(100 \mathrm{~g})-($ Lipid + Protein + Mineral $) \times 100$

\subsection{Mineral contents}


Atomic Absorption Spectrometry (AAS) was used to detect the mineral contents. The samples were digested through the wet digestion method using perchloric acid as solvent. The digested samples were filtered in glass filters and diluted with distilled water to make a 100ml volume. (Ghaedi et al. 2007). Calculations were made based on the following formula.

$$
\text { Mineral content }=\frac{(\text { AAS result }) \times \text { Volume of sample } \times \text { Dilution factor }}{\text { Weight of Sample }}
$$

\subsection{Data Analysis}

Data obtained was analyzed using Mstat-C GenStat software for ANOVA and LSD test at 0.05 level of probability (Steel and Torrie,1980).

\section{Results}

The findings of this study suggest that nitrogen and phosphorus, like other environmental factors, affect the percentage biochemical composition of (Lemna minor). All the parameters showed variation with change in the concentration of nutrients supplied to the growth medium.

\subsection{Proteins}

Protein contents markedly increased in plants grown in 30ppm NP concentration. The highest percentage for protein obtained on this treatment was $(33.0 \mathrm{~g} / 100 \mathrm{~g})$ as shown in (Table- 1$)$. The lowest $(27 / 100 \mathrm{~g})$ was obtained from the control. With an increase in nitrogen concentration, protein contents increased markedly. A 20ppm increase in nitrogen concentration elevated protein contents by $2 \mathrm{~g} / 100 \mathrm{~g}$. A similar rise in protein contents was also observed with an increase in $\mathrm{P}$ concentration. The result of the collective application of NP was more significant than the independent application of $\mathrm{N}$ and $\mathrm{P}$.

\subsection{Lipids}

A significant effect of the applied growth medium nutrients is depicted in Table-1. The content of lipid $(10 \mathrm{mg} / 100 \mathrm{~g})$ as the highest was recorded in plants grown in 30ppm NP medium. This value is followed by $(10 \mathrm{mg} / 100 \mathrm{~g})$ lipid contents for plants grown in the 20ppm NP medium. Statistical analysis of the data regarding lipid content as depicted in (Table-1) revealed that variation in nutrients of growth medium has a significant effect on the lipid content of duckweed.

The lowest value of $(4.67 \mathrm{~g} / 100 \mathrm{~g})$ was noted in plants growing in $10 \mathrm{ppm} \mathrm{N}$ medium and control.

\subsection{Carbohydrates}

The results of the contents of carbohydrates are shown in Table-1. A maximum level of carbohydrates $(60 \mathrm{~g} / 100 \mathrm{~g}$ dry weight) was observed in the plants grown in 30ppm NP medium and $(59 \mathrm{~g} / 100 \mathrm{~g})$ for $20 \mathrm{ppm}$ respectively. The control group showed the minimum level of carbohydrates $(52 \mathrm{~g} / 100 \mathrm{~g})$. 
Independent application of $\mathrm{N}$ and $\mathrm{P}$ at the rate of 30ppm enhanced the carbohydrate content by $(2 \mathrm{~g} / 100 \mathrm{~g})$.

Table-1 Effect of Growth Medium Nutrient Concentration (N, P, and NP) on Protein, Lipid, and Carbohydrate Contents of Duckweed (L. minor).

\begin{tabular}{|llll|}
\hline Nutrients (ppm) & \multicolumn{3}{l|}{ Proximate Biochemical Composition (g/100g) } \\
\cline { 2 - 4 } & Protein & Lipid & Carbohydrate \\
\hline $10 \mathrm{~N}$ & $27.6 \pm 0.8^{\mathrm{ef}}$ & $4.67 \pm 1.0^{\mathrm{f}}$ & $54.6 \pm 1.0^{\mathrm{d}}$ \\
\hline $20 \mathrm{~N}$ & $28.7 \pm 0.9^{\mathrm{de}}$ & $5.67 \pm 2.0^{\mathrm{e}}$ & $56.0 \pm 1.5^{\mathrm{c}}$ \\
\hline $30 \mathrm{~N}$ & $29.0 \pm 0.8^{\mathrm{de}}$ & $6.00 \pm 1.5^{\mathrm{e}}$ & $55.6 \pm 1.5^{\mathrm{cd}}$ \\
\hline $10 \mathrm{P}$ & $29.3 \pm 0.5^{\mathrm{d}}$ & $6.67 \pm 1.5^{\mathrm{d}}$ & $57.0 \pm 1.0^{\mathrm{bc}}$ \\
\hline $20 \mathrm{P}$ & $30.0 \pm 0.7^{\mathrm{cd}}$ & $7.00 \pm 2.0^{\mathrm{d}}$ & $57.6 \pm 0.5^{\mathrm{ab}}$ \\
\hline $30 \mathrm{P}$ & $31.0 \pm 2.0^{\mathrm{bc}}$ & $8.00 \pm 0.8^{\mathrm{c}}$ & $58.3 \pm 2.0^{\mathrm{ab}}$ \\
\hline $10 \mathrm{NP}$ & $31.0 \pm 0.8^{\mathrm{bc}}$ & $8.00 \pm 0.9^{\mathrm{c}}$ & $59.0 \pm 1.7^{\mathrm{ab}}$ \\
\hline $20 \mathrm{NP}$ & $32.0 \pm 1.5^{\mathrm{ab}}$ & $9.00 \pm 0.5^{\mathrm{b}}$ & $59.3 \pm 1.8^{\mathrm{ab}}$ \\
\hline $30 \mathrm{NP}$ & $33.0 \pm 2.0^{\mathrm{a}}$ & $10.0 \pm 1.0^{\mathrm{a}}$ & $60.0 \pm 1.0^{\mathrm{a}}$ \\
\hline Control & $27.0 \pm 0.5^{\mathrm{f}}$ & $4.67 \pm 0.5^{\mathrm{f}}$ & $52.3 \pm 1.0^{\mathrm{e}}$ \\
\hline LSD (p $\leq 0.05)$ & 1.61 & 0.622 & 3.84 \\
\hline Means in the table with different subscripts are significantly different $(\mathrm{p} \leq 0.05)$ using the LSD test. \\
\hline 3.4. Minerals & & & \\
\hline
\end{tabular}

Five elements, $\mathrm{Ca}, \mathrm{Mg}, \mathrm{Fe}, \mathrm{Mn}$, and $\mathrm{Zn}$ showed the following results with the change in the level of $\mathrm{N}, \mathrm{P}$, and NP.

\subsubsection{Calcium (Ca)}

Analysis of the data manifested a significant effect of altering nutrient concentrations on the elemental composition of $\mathrm{Ca}$. With an increase in nitrogen concentration, a gradual increase in Ca content resulted. Phosphorus concentration of $30 \mathrm{ppm}$ has a maximum increasing effect $(30 \mathrm{mg} / 100 \mathrm{~g})$ in calcium content while the combined effect of NP has a similar effect at all levels of concentrations.

\subsubsection{Magnesium (Mg)}


A maximum of $(33 \mathrm{mg} / 100 \mathrm{~g}) \mathrm{Mg}$ content was observed for plants grown in 30ppm NP followed by $(32 \mathrm{mg} / 100 \mathrm{~g})$ for plants grown in 20ppm NP. Thus (Mg) content was fortified by the combined application of $\mathrm{N}$ and $\mathrm{P}$. The increase in the concentration of $\mathrm{N}$ increased the quantity of $\mathrm{Mg}$ at the same time increase in $\mathrm{P}$ concentration to 30ppm also boosted up the percentage of the element. In all cases, whether the two nutrients N \&P are applied individually or in combination increase the total of $\mathrm{Mg}$ in the biomass of the plant.

\subsubsection{Iron (Fe)}

The maximum level of Fe $(36 \mathrm{mg} / 100 \mathrm{~g})$ was recorded for plants growing in the $30 \mathrm{ppm} \mathrm{N}$ and $30 \mathrm{ppm} \mathrm{NP}$ as shown in Table-2. The lowest content of Fe was recorded for $10 \mathrm{ppm} \mathrm{N}$ which is $25 \mathrm{mg} / 100 \mathrm{~g}$. The result shows a significant relationship between the treatments and Fe contents.

\subsubsection{Manganese (Mn)}

The fraction of $\mathrm{Mn}$ varied with the change in the nutrient levels of the growth medium. A higher value of the element $(3.7 \mathrm{mg} / 100 \mathrm{~g})$ was noted in the treatment $10 \mathrm{ppm}$ NP. Independent application of $\mathrm{N}$ and $\mathrm{P}$ also showed a significant effect. The minimum value of $(0.7 \mathrm{mg} / 100 \mathrm{~g})$ was depicted for control.

\subsubsection{Zinc (Zn)}

The composition of zinc is depicted in Table-2. The maximum concentration of zinc $0.082 \mathrm{mg} / 100 \mathrm{~g}$ ) was obtained for plants grown in the medium of 20ppm NP. The independent application of $\mathrm{N}$ and $\mathrm{P}$ also showed a significant change, but the more pronounced effect was observed in the combined application of NP.

Table-2 Elemental composition of Duckweed (Lemna minor) after treatment with variable $(N)$ and $(P)$ combinations 


\section{Proximate Composition of Nutrients $(\mathrm{mg} / 100 \mathrm{~g})$}

\begin{tabular}{|c|c|c|c|c|c|}
\hline \multicolumn{6}{|l|}{ Nutrients (ppm) } \\
\hline & $\mathrm{Ca}$ & $\mathrm{Mg}$ & $\mathrm{Fe}$ & Mn & $\mathrm{Zn}$ \\
\hline $10 N$ & $35 \pm 0.03^{b c}$ & $27 \pm 0.03^{f g}$ & $25 \pm 0.41^{b c}$ & $3.2 \pm 0.05 \mathrm{~cd}$ & $0.07 \pm 0.05 c$ \\
\hline $20 N$ & $38 \pm 0.02^{b}$ & $28 \pm 0.03^{\text {efg }}$ & $33 \pm 0.35^{a}$ & $2.4 \pm 0.15 d$ & $0.03 \pm 0.01 b$ \\
\hline $30 \mathrm{~N}$ & $40 \pm 0.25^{a}$ & $28 \pm 0.03^{\text {def }}$ & $36 \pm 0.55^{a}$ & $3.2 \pm 0.40 \mathrm{~cd}$ & $0.05 \pm 0.02 a$ \\
\hline $10 P$ & $26 \pm 0.05^{\mathrm{cd}}$ & $29 \pm 0.03^{\text {cdef }}$ & $23 \pm 0.49^{c}$ & $0.7 \pm 0.03 \mathrm{~cd}$ & $0.04 \pm 0.03 d$ \\
\hline $20 P$ & $26 \pm 0.45^{d}$ & $30 \pm 0.03^{\text {bcde }}$ & $34 \pm 0.65^{a}$ & $3.2 \pm 0.25 d$ & $0.06 \pm 0.01 a$ \\
\hline $30 \mathrm{P}$ & $30 \pm 0.70^{a}$ & $31 \pm 0.03^{\mathrm{abcd}}$ & $35 \pm 0.47^{a}$ & $0.8 \pm 0.20 \mathrm{~cd}$ & $0.04 \pm 0.01 \mathrm{~cd}$ \\
\hline $10 \mathrm{NP}$ & $26 \pm 0.09^{c d}$ & $32 \pm 0.03^{\mathrm{abc}}$ & $34 \pm 0.75^{a}$ & $3.7 \pm 0.18 a$ & $0.06 \pm 0.05 \mathrm{~cd}$ \\
\hline $20 \mathrm{NP}$ & $24 \pm 0.08^{d}$ & $32 \pm 0.03^{\mathrm{ab}}$ & $35 \pm 0.65^{a}$ & $2.5 \pm 0.32 c$ & $0.08 \pm 0.02 c$ \\
\hline $30 \mathrm{NP}$ & $24 \pm 0.02^{d}$ & $33 \pm 0.03^{a}$ & $36 \pm 0.40^{\mathrm{a}}$ & $2.8 \pm 0.01 \mathrm{c}$ & $0.06 \pm 0.10 \mathrm{~cd}$ \\
\hline Control & $32 \pm 0.09^{\mathrm{bcd}}$ & $25 \pm 0.03^{g}$ & $26 \pm 0.55^{b}$ & $0.7 \pm 0.41 b$ & $0.04 \pm 0.01 \mathrm{~cd}$ \\
\hline $\operatorname{LSD}(p \leq 0.05)$ & 0.8 & 0.07 & 0.15 & 0.08 & 0.05 \\
\hline
\end{tabular}

\section{Discussion}

The protein contents of the duckweed showed a remarkable increase with the combined application of NP. Both nitrogen and phosphorus supply increases protein contents in duckweed. The crude protein content of duckweeds grown in levels of the nutrient solution may increase from (7-45\%) of the dry biomass depending on nitrogen availability (Culley et al, 1981). Nutrient deficiency, slow growth has been reported to result in protein level as low as (7\%) of dry matter (Landolt and Kandeler, 1987).

This showed lipid contents increase with the application of $\mathrm{N}$ and $\mathrm{P}$. For most of the investigators the effect of $\mathrm{N}, \mathrm{P}$ application has resulted in no significant change in the total lipid content accumulation but only changed the proportion of different fatty acids has resulted (Appelqvist 1968). Both $N$ and $P$ are important constituents of biochemical machinery and cellular metabolism. Nitrogen being a part of chlorophyll brings a major change in photosynthetic activity when deficient. Leng et al., (1995) demonstrated that unfertilized lagoon growing duckweeds produce as many as (4.4\%) of lipid of total dry mass. An increase in nutrient availability and continuous exposure to sunlight increase the growth of the plant and ultimately result in an increase in the macromolecular composition. 
Our study suggests an increase in carbohydrate components with the increase of both $\mathrm{N}$ and $\mathrm{P}$. Both elements act as growth control factors because these are key elements in the biochemistry of every plant. Menendez et al., (2002) stated that $\mathrm{N}$ enrichment to Chaetomorpha linum causes an increase in chlorophyll content of the plant, and hence more carbon fixation resulted. Phosphorus has no direct effect on chlorophyll contents but an indirect effect on carbohydrate metabolism. It is a component of sugar-phosphate intermediates of both photosynthesis and respiration. Also, it is a part of all those reactions which involve ATP and is actively involved in the assimilation of photosynthetic products.

Phosphorus application increases the uptake of (Ca) in plants. Xiao et al., (2013) showed that (Ca) uptake was higher after the application of $\mathrm{P}$ in Apium graveolens $\mathrm{L}$. Plant cells can accumulate nutrients at much higher concentrations than are present in their root zone. This allows roots to extract nutrients from the soil solution where they are present in very low concentrations. Mobility of nutrients within the plant depends largely upon transport through cell membranes, which requires energy to transport against the concentration gradient. Here again, ATP and other high-energy phosphate compounds provide the needed energy. Calcium uptake in the root is to a large extent genetically controlled and is relatively less affected by (Ca) supply to the root medium, provided that $(\mathrm{Ca})$ availability is adequate for normal growth (Kirkby and Pilbeam 1984).

The importance of magnesium cannot be negated in plant growth and development. Besides the role of $(\mathrm{Mg})$ in chlorophyll structure and as an enzyme cofactor, another essential role of $(\mathrm{Mg})$ in plants is in the export of photosynthates, which when impaired culminates to enhanced degradation of chlorophyll in $\mathrm{Mg}$ deficient leaves, resulting in higher oxygenase activity of RuBP carboxylase (Marschner and Cakmak, 1989).

Most plant species rely on reduction-based ( $\mathrm{Fe}$ ) uptake, and much progress has been made in the past few years concerning hormonal, molecular, and whole-plant aspects of its regulation, this review focuses on the Strategy I-type mechanism of Fe acquisition. There are several other recent reviews covering iron uptake in yeast (Yamaguchi et al., 1996).

Trace element like $(\mathrm{Mn})$ is available for biological absorption at moderately acidic $\mathrm{pH}$ (Gambrell and Patrick 1988; Jackson, et al., 1993). Therefore, the absorption of $\mathrm{Mn}$ is regulated by the presence of phosphate in the root zone.The absorption of $\mathrm{Zn}$ is much dependent on the $\mathrm{pH}$ factor. It has been observed that the absorption of micronutrients increases with low pH. Jackson et al., (1993) concluded that low pH coupled with mild redox increases the availability of micronutrients.

\section{Conclusion}

1. The effect of both $\mathrm{N}$ and $\mathrm{P}$ was significant on the biomass production, crop growth, protein, lipid, carbohydrate, and mineral contents of L. minor L.

2. The proximate composition of the plant showed that it contains a fair quantity of all nutrients like proteins, essential amino acids, lipids, carbohydrates, and minerals. 
3. Due to its rapid growth, it produces a lot of biomasses, and its short life cycle provides us an opportunity to be harvested twice a week.

4. Its chemical composition is sensitive to the growing conditions and its biochemical contents like proteins, minerals, and carbohydrates can be manipulated by the nutritional status of the growth media.

\section{Abbreviations}

CRD = Completely Randomized Design

WSCI $=$ Weed Science

AAS = Atomic Absorption Spectrometry

\section{Declarations}

\section{Ethics approval and consent to participate}

The study was conducted after the approval of the advanced study committee, Department of Weed and Plant Protection Science, the University of Agriculture KP, Pakistan. It is, therefore, declared that no ethical issue is involved in the study.

\section{Consent for Publication}

The study does not contain any personal data and therefore, does not need any consent for publication.

\section{Availability of data and material}

The data analyzed and used in the current study can be made available upon special request from the corresponding author.

\section{Competing Interests}

The authors declare no conflict of interest.

\section{Funding}

The study was funded by the Higher education commission of Pakistan.

\section{Authors' contributions}

Hafiz Ullah ${ }^{\star 1}=$ Conducted the research. 
Bakhtiar $\mathrm{Gul}^{2}=$ Identified the plant sample and designed the research.

Haroon $\mathrm{Khan}^{3}=$ Designed the research.

Naveed Akhtar $^{4}=$ Performed statistical analysis

Khushnood Ur Rehman ${ }^{5}=$ Wrote the manuscript.

Umar Zeb ${ }^{6}=$ Wrote the manuscript

\section{Acknowledgment}

The authors acknowledge the assistance of the Higher Education Commission of Pakistan to conduct the research.

\section{References}

1. Adejinmi, 0.0. 2000. The Chemical Composition and nutritional potential of soldier fly larvae (Hermetia elucens) in poultry rations. A PhD thesis submitted to the University of Ibadan. p. 292.

2. Adikwu, I. A. 2003. A review of aquaculture nutrition in aquaculture development in Nigeria. In Proceeding of National Workshop on Fish Feed Development and Feeding Practices in Aquaculture. Fisheries Society of Nigeria/NIFFR/FAO-NSPFS Held at NIFFR, New Bussa, Nigeria Sept. 2003.

3. Appelqvist, L. Å. (1968). Lipids in Cruciferae: II. Fatty acid composition of Brassica napus seed as affected by nitrogen, phosphorus, potassium and sulfur nutrition of the plants. Physiologia Plantarum, 21(2), 455-465.

4. Appenroth, K.J., K. Krech, A. Keresztes, W. Fischer, and H. Koloczek. 2010. Effects of nickel on the chloroplasts of the duckweeds Spirodela polyrhiza and L. minor and their possible use in biomonitoring and phytoremediation. Chemosphere, 78(3):216-223.

5. Cheng, J. J., and A. M. Stomp. 2009. Growing duckweed to recover nutrients from wastewaters and for production of fuel ethanol and animal feed. Clean Soil, Air and Water, 37: 17-26.

6. Culley, D. D., E. Rejmánková, J. Květ, and J.B. Frye. 1981. Production, chemical quality and use of duckweeds (Lemnaceae) in aquaculture, waste management, and animal feeds. J. World mariculture society, 12(2): 27-49.

7. Fagbenro, A. O., E. Adeparusi. and O.O. Fapohunda. 2003. Feedstuff and dietary substitution for farmed fish in Nigeria. In Pan African Fish and Fisheries Conference Contonou, Benin Republic. Book of abstracts, 276.

8. Gambrell, R.P. and W.H. Patrick . 1988. The influence of redox potential on the environmental chemistry of contaminants in soils and sediments. In The ecology and management of wetlands. Springer US, 319-333 
9. Haustein, A.T., R.H. Gillman, P.W. Skillicorn, V. Vergara, V. Guevara and A. Gastanaduy. 1990.

Duckweed, a useful strategy for feeding chickens: Performance of layers feed with sewage-grown Lemanceae species. Poult. Sci., 69: 1835-1844.

10. Islam, K. M. S., M. Shahjalal, A.M.M. Tareque, and M.A.R. Howlider. 1997. Complete replacement of dietary fish meal by duckweed and soybean meal on the performance of broilers. Asian Australian J. Animal Sci., 10: 629-634.

11. Jackson, R.B. and M.M. Caldwell. 1993. The scale of nutrient heterogeneity around individual plants and its quantification with geostatistics. Ecology, 74(2): 612-614.

12. Journey, W. K., P. Skillicorn, and W. Spira. 1993. Duckweed aquaculture. A new aquatic farming system for developing countries. The World Bank, Washington DC.

13. Kirkby, E.A. and D.J. Pilbeam. 1984. Calcium as a plant nutrient. Plant, Cell and Envir., 7(6):397-405.

14. Lancar, L. and Krake, K. (2002). Aquatic Weeds \& their Management. International Commission on irrigation and Drainage. p.1- 65.

15. Landolt, E. and R. Kandeler. 1987. Bio-systematic investigations in the family of duckweeds (Lemnaceae), 4: 211-34.

16. Leng, R.A., J.H. Stambolie, and R. Bell. 1995. Duckweed-a potential high-protein feed resource for domestic animals and fish. Livestock Research for Rural Development, 7(1):36.

17. Logsdon G. 1989. Is duckweed the ultimate wastewater purifier? Biocycle, 30(6):70-71

18. Marschner, H. and I. Cakmak. 1989. High light intensity enhances chlorosis and necrosis in leaves of zinc, potassium, and magnesium deficient bean (Phaseolus vulgaris) J. plant. Physiol., 134(3): 308315.

19. Mbagwu, I. G., and H.A. Adeniji. 1988. The nutritional content of duckweed (Lemna paucicostata Hegelm.) in the Kainji Lake area, Nigeria. Aq. Bot., 29(4): 357-366.

20. McClure, J.W. and R.E. Alston. 1966. A chemotaxonomic study of the Lemnaceae. Amer. J. Bot., 53: 849-860.

21. Men, B.X., B. Ogle and J.E. Lindberg. 2001. Use of duckweed as a protein supplement for growing ducks. Asian-Aust. J. Anim. Sci., 14: 1741-1746.

22. Menendez, M., J. Herrera, and F.A. Comin. 2002. Effect of nitrogen and phosphorus supply on growth, chlorophyll content and tissue composition of the macroalga Chaetomorpha linum in a Mediterranean Coastal Lagoon. Sci. Marina., 66(4): 355-364.

23. Ngou, J. N. and Mafeni, J. M. (1983). The value of cotton seed meal in poultry diets. Annual Report, Institute of Animal Research, Manikoon. pp. 34-36.

24. Porath, D., B. Hepher, and A. Koton. 1979. Duckweed as an aquatic crop: evaluation of clones for aquaculture. Aq. Bot., 7: 273-278.

25. Samnang, H. 1999. Duckweed versus ground soya beans as supplement for scavenging native chickens in an integrated farming system. Livestock for Rural Development, 11(1). 
26. Sońta, M., Rekiel, A., \& Batorska, M. (2019). Use of duckweed (Lemna L.) in sustainable livestock production and aquaculture-a review. Annals of Animal Science, 19(2), 257- 271.

27. Steel, R.G. and J.H. Torrie. 1980. Analysis of covariance. Principles and procedures of statistics: $A$ Biometrical Approach, 401-437.

28. Stephenson, M., G. Turner, P. Pope, J. Colt, and A. Knight. 1980. The use and potential of aquatic species for wastewater treatment. Appendix A: The environmental requirements of aquatic plants.

29. Truax, R. E., D.D. Culley, M. Griffith, W.A. Johnson and J.P. Wood. 1972. Duckweed for chick feed. La Agric.,16(1): 8-9.

30. Vang, N.D., T.C. Xuan, P.D. Tien, L.T. Nga, and N.M. Hung. 2001. Meat production of DongTao breed and crossbred Dong Tao x TamHoang. In Final Report of Sci. Technol. Project, 169-179.

31. Whetstone, J. M. (2005). Aquatic weed control, HGIC1714. Clemson University.

32. Xiao, Y., Fang, Y., Jin, Y., Zhang, G., \& Zhao, H., 2013. Culturing duckweed in the field for starch accumulation. Industrial crops and products, 48: 183-190

33. Yamaguchi-Iwai, Y., Stearman, R., Dancis, A. and Klausner, R.D., 1996. Iron-regulated DNA binding by the AFT1 protein controls the iron regulon in yeast. The EMBO Journal, 15(13): 377. 